\title{
INTRACELLULAR INJECTION WITH HORSERADISH PEROXIDASE OF PHYSIOLOGICALLY CHARACTERIZED STELLATE AND BUSHY CELLS IN SLICES OF MOUSE ANTEROVENTRAL COCHLEAR NUCLEUS ${ }^{1}$
}

\author{
SHU HUI WU AND DONATA OERTEL ${ }^{2}$ \\ Department of Neurophysiology, University of Wisconsin, Madison, Wisconsin 53706
}

Received September 9, 1983; Revised December 19, 1983; Accepted January 6, 1984

\begin{abstract}
Nissl-stained tissue from brain slice preparations of the anteroventral cochlear nucleus of the mouse resembles tissue fixed in situ. Multipolar, spherical, globular, and granule cells can be distinguished after intracellular injection with horseradish peroxidase (HRP). Stellate cells have relatively large dendritic fields; their axons have collaterals which terminate within the cochlear nuclear complex. Bushy cells have smaller dendritic fields; where they can be seen, axons have no collaterals. Granule cells have few short dendrites; their very fine axons branch close to the cell body and could be followed only for short distances.

Intracellular recordings from six stellate cells labeled by intracellular injection of HRP revealed that they have linear current-voltage relationships around the resting potential and that they respond to suprathreshold depolarization with large, regularly firing action potentials. Intracellular recordings from four bushy cells, also labeled by injection of HRP, showed that these cells have nonlinear current-voltage relationships around the resting potential and that they respond to suprathreshold depolarizations with only one or two small action potentials.

The anatomical and physiological features of bushy cells reduce summing in time and space and make bushy cells well suited to preserve the firing patterns of auditory nerve inputs. The anatomical and physiological features of stellate cells, in contrast, allow summing in time and space.
\end{abstract}

In the mammalian auditory system, sensory information is contained not only in the spatial pattern of activation of neurons but also in their temporal firing patterns. The timing of cellular discharges in the first stages of the auditory pathway is precise to within fractions of a millisecond. Natural sounds are complex; they typically contain energy at many different frequencies and change rapidly in time. How these spectrally and temporally complex signals are processed by the nervous system is intriguing but difficult to study.

Sound is converted to electrical signals by hair cells in

\footnotetext{
${ }^{1}$ We are grateful for the expert help from C. Dizack in preparing the illustrations, from T. Stewart in photography, from J. Eckleberry, J. Meister, and I. Siggelkow in preparing the tissue histologically, from $H$. Ludwig and $P$. Luther in technical matters, and from $H$. Jensen for help with typing. We also thank Dr. J. E. Hind for reading the manuscript critically. This work was funded by Grant NS 17590 from the National Institutes of Health.

${ }^{2}$ To whom correspondence should be addressed, at Department of Neurophysiology, University of Wisconsin, 283 Medical Sciences Building, Madison, WI 53706.
}

the cochlea. Auditory nerve fibers carry signals from the hair cells to the cochlear nuclear complex, the first major integrative stage in the auditory pathway. A short distance from their point of entry into the brainstem, auditory nerve fibers bifurcate, innervating the anteroventral cochlear nucleus (AVCN) with the ascending branch and the posteroventral (PVCN) and dorsal cochlear nuclei (DCN) with the descending branch. Auditory nerve fibers provide each of these three regions of the cochlear nuclear complex with a tonotopic representation of sound (Rose et al., 1959).

Golgi staining of the AVCN of cats and mice shows that it contains two major cell types, stellate and bushy cells (Lorente de Nó, 1933b, 1981; Brawer et al., 1974; Tolbert et al., 1982; Webster and Trune, 1982). Bushy cells correspond to the large spherical cells in the anterior division (Cant and Morest, 1979a; Webster and Trune, 1982) and globular cells in the posterior division (Brawer et al., 1974; Tolbert and Morest, 1982) of the AVCN of Nissl-stained tissue. In the cat, bushy cells occur predominantly in the area anterior to and including the region of bifurcation of the auditory nerve fibers, the interstitial 
area (Brawer et al., 1974; Tolbert and Morest, 1982). In the mouse, bushy cells are, in addition, found in the lateral parts of the cochlear nuclear complex posterior to the interstitial area (Webster and Trune, 1982; Willard and Ryugo, 1983). Stellate cells are found throughout the ventral cochlear nuclei. They have variable shapes and probably represent more than a single cell type in the mouse (Webster and Trune, 1982), as they do in the cat (Cant, 1981).

Auditory nerve fibers innervate all cells in the cochlear nuclear complex. Their contacts with bushy cells are remarkable in that the terminals of a single fiber, an end bulb of Held, may cover almost half of a bushy cell body with multiple synaptic contacts (Lorente de Nó, 1933a; Lenn and Reese, 1966; Brawer and Morest, 1975; Cant and Morest, 1979b; Ryugo and Fekete, 1982). The endings of auditory nerve fibers on other cell types consist of more conventional button synapses.

In a brain slice preparation of the cochlear nuclear complex, the intrinsic properties of cclls can be studied by measuring their responses to intracellularly injected current. The characteristics of synapses between auditory nerve fibers and postsynaptic cells can be studied by recording responses to electrical stimulation of the stump of the auditory nerve (Oertel, 1983). Cells in the AVCN of the mouse from which intracellular recordings were made have two types of electrical characteristics. Cells of type I have linear current-voltage relationships and respond to steady depolarizing current with large, regularly firing action potentials. Cells of type II, in contrast, have nonlinear current-voltage relationships, and they respond to steady depolarizing current with one or two small action potentials. Cells of both types respond to electrical stimulation of the auditory nerve with an early excitatory and a later inhibitory synaptic potential. Excitation presumably results from direct auditory nerve input; the inhibition is probably mediated through interneurons. With intracellular injections of horseradish peroxidase (HRP), we have labeled cells whose electrical characteristics had been determined. We show below that stellate cells have linear current-voltage relationships and that they fire large, regular action potentials when they are depolarized; in other words, stellate cells have type I characteristics. Bushy cells have nonlinear current-voltage relationships and they fire only one or two small action potentials when they are depolarized; in other words, they have type II characteristics (Oertel, 1983).

\section{Materials and Methods}

The preparation of brain slices of the AVCN has been described (Oertel, 1983). Briefly, young mice of the inbred strain NFS, between 2 and 4 weeks old, were used. The brain was quickly removed from the skull and the appropriate block of tissue was trimmed with a razor blade. The tissue was then glued to a Teflon block with a cyanoacrylate glue (Krazyglue). The most lateral, approximately parasagittal slice of the brainstem, $250 \mu \mathrm{m}$ thick, was cut with an Oscillating Tissue Slicer (Frederick Haer, Inc.) and transferred to the recording chamber. The slice was illuminated from below with a darkfield condenser. Saline flowed continuously through the 0.3$\mathrm{ml}$ chamber at a rate of about $8 \mathrm{ml} / \mathrm{min}$. The chamber allows saline to flow both over and under the slice. The composition of the saline was: $124 \mathrm{~mm} \mathrm{NaCl}, 1.2 \mathrm{mM}$ $\mathrm{KH}_{2} \mathrm{PO}_{4}, 1.3 \mathrm{~mm} \mathrm{MgSO}$, $2.4 \mathrm{mM} \mathrm{CaCl}_{2}, 10 \mathrm{~mm}$ dextrose, and $26 \mathrm{~mm} \mathrm{NaHCO}$. At $35^{\circ} \mathrm{C}$, when it was saturated with $5 \% \mathrm{CO}_{2}$ and $95 \% \mathrm{O}_{2}$, the $\mathrm{pH}$ was 7.4 (Dingledine et al., 1980).

Standard methods were used to make electrophysiological recordings. In early experiments electrodes were filled with $4 \%$ HRP (Sigma, type VI) $0.5 \mathrm{M} \mathrm{KCl}, 0.04 \mathrm{M}$ Tris, $\mathrm{pH} 8.6$, which had been filtered through $0.2-\mu \mathrm{m}$ pore nitrocellulose filters (Bioanalytical Systems, Inc.). Electrodes were filled using the method of Haberly and Bower (1981) and were beveled with a jet-stream beveler (Ogden et al., 1978) to have resistances between 100 and 150 megohms. With this type of electrode it was exceedingly difficult to obtain good recordings from any cells. Action potentials about $5 \mathrm{mV}$ in amplitude enabled us to recognize the presence of stellate cells, but only a single bushy cell was injected, presumably because the electrodes damage the cells so much that no responses to electrical stimulation of the auditory nerve could be measured. Much better results were obtained when electrodes were pulled to be finer, backfilled with $2 \% \mathrm{HRP}$, $2 \mathrm{M}$ potassium acetate, $\mathrm{pH} 7.5$, and dipped into $2 \%$ dichlorodimethylsilane in $\mathrm{CCl}_{4}$. These electrodes had resistances between 80 and 120 megohms and did not need to be beveled. Injections were made with current pulses $100 \mathrm{msec}$ long, 5 to $10 \mathrm{nA}$, presented 5 times/sec.

Between 1 and 10 injections were made into a slice. The positions of injected cells were recorded on a sketch of the slice. More than 30 min after the final injection had been made, the slice was fixed in $1.25 \%$ glutaraldehyde, $0.1 \mathrm{M}$ phosphate buffer, $\mathrm{pH} 7.4$, for $35 \mathrm{~min}$. The tissue was left in $0.1 \mathrm{M}$ Tris, $\mathrm{pH} 7.4$, overnight. On the following day the tissue was processed according to the method of Graham and Karnovsky (1966) with cobalt intensification (Adams, 1977). The slice was then embedded in $2 \%$ agar, $0.1 \mathrm{M}$ phosphate buffer at $45^{\circ} \mathrm{C}$ and, after the agar had hardened, it was immersed in $25 \%$ sucrose, $0.1 \mathrm{M}$ phosphate buffer, overnight. Frozen sections, $80 \mu \mathrm{m}$ thick, parallel to the plane of the slice were cut, mounted, dehydrated, and counterstained with cresyl violet.

Each slice was reconstructed using camera lucida drawings of the sections at low magnification. Camera lucida reconstructions of the HRP-filled cells were made at high power. Drawings of cells are shown together with drawings of the slices in Figures 2 to 5 . Their positions were clearly correlated with the positions of injections on the original sketches so that accurate correlations of morphology could be made with the electrophysiological recordings.

\section{Results}

Nissl-stained tissue. Nissl-stained tissue from brain slice preparations resembles tissue fixed by perfusion through the heart. Figure $1 A$ shows the most lateral of four parasagittal sections of a brainslice preparation which was fixed after $7 \mathrm{hr}$ in vitro and subsequently sectioned. Auditory nerve fibers enter the cochlear nuclear complex ventrally, forming a triangular region of bifurcation, the interstitial area. Cells of the ventral cochlear nuclei flank the interstitial area on both sides. 


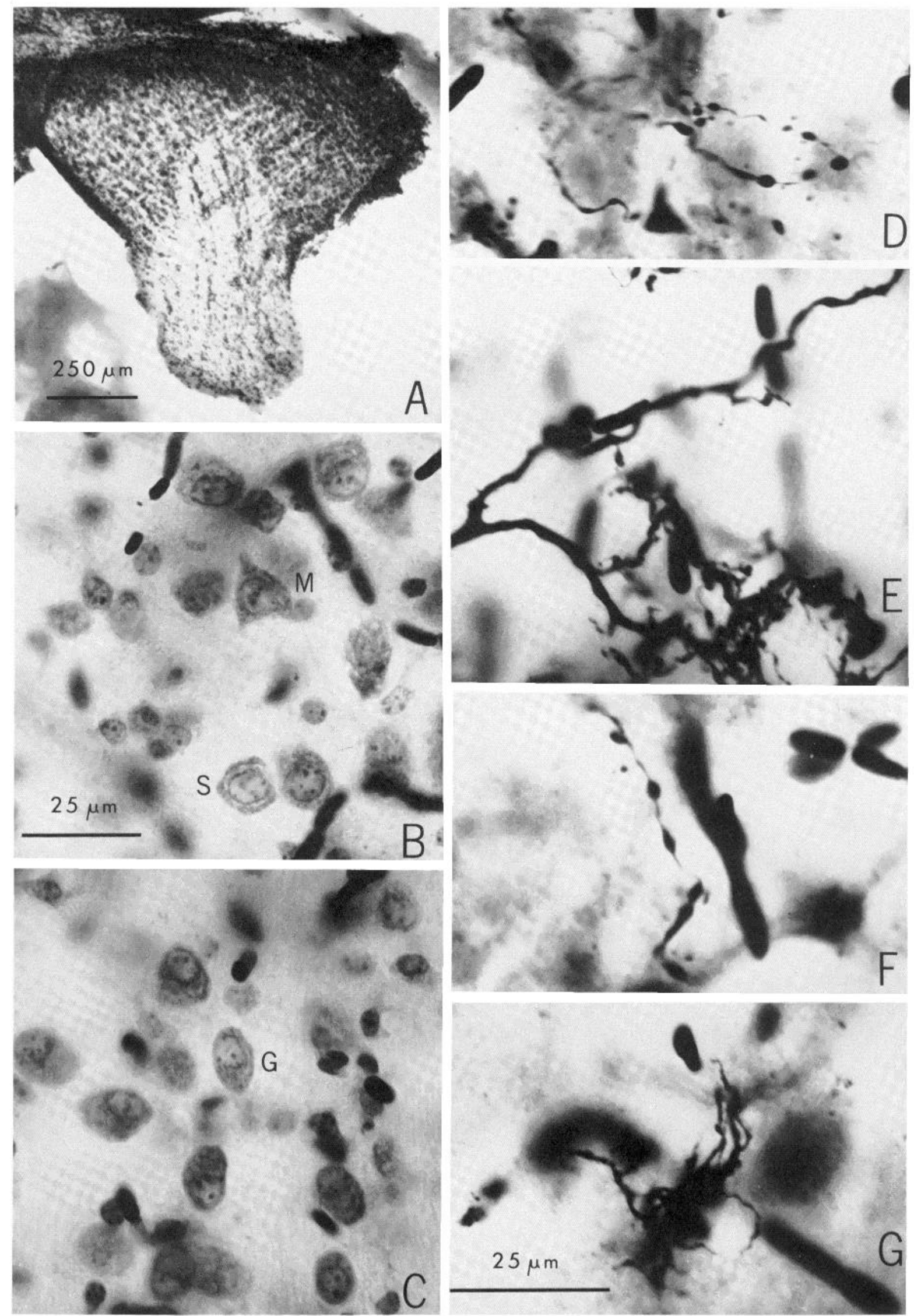

Figure 1. Photomicrographs of tissue in brain slice preparations maintained in vitro for 3 to $7 \mathrm{hr}$. $A$, The most lateral of four sections, $80 \mu \mathrm{m}$ thick, of a slice containing the auditory nerve and cells belonging to the AVCN, stained with cresyl violet but not processed for peroxidase. The stump of the auditory nerve is at the bottom; the triangular region of bifurcation of auditory nerve fibers just above the nerve stump is the interstitial area. The tissue both anterior (right) and posterior (left) to the interstitial area belongs to the AVCN. B, Multipolar cell $(M)$ and spherical cell $(S)$ in the anterior part of the AVCN. $C$, Globular cell $(G)$ in the interstitial area in rows between fascicles of auditory nerve fibers. $D-G$, Photographs of processes of cells that were stained with HRP. D, Terminals of axon collaterals of stellate cell 2 . E. Portion of the dendritic arbor of stellate cell 2 . $F$, Beaded dendrite of stellate cell 9. G, Dendrites of bushy cell 12 . Red blood cells have intrinsic peroxidase and are stained black in the tissue depicted in panels $B$ to $G$. Scales $(25 \mu \mathrm{m})$ are the same for $B$ and $C$ and for $D$ through $G$. 
Four types of cells can be distinguished in Nisslstained tissue. Spherical cells (Fig. 1B) are found only anterior to the interstitial area, anterior and medial to the tissue shown in Figure 1A. Spherical cells have round cell bodies with centrally located nuclei. It was not possible to distinguish a perinuclear ring in this tissue, perhaps because the sections were $80 \mu \mathrm{m}$ in thickness (Martin, 1981; Webster and Trune, 1982; Willard and Ryugo, 1983). Globular cells, oval in shape with eccentric nuclei, are found more posterior, in and around the interstitial area (Fig. $1 C$ ). Multipolar cells (Fig. $1 B$ ), cells whose Nissl substance extends slightly into the dendrites, giving these cells their characteristic appearance, are found in all parts of these brain slice preparations. Granule cells are abundant in the granule cell layer which covers the lateral surface of the ventral cochlear nucleus.

In the cat, the caudal edge of the interstitial area separates the AVCN and the PVCN (Brawer et al., 1974; Tolbert and Morest, 1982). This border cannot be used to separate the AVCN and PVCN of the mouse (Willard and Ryugo, 1983). Since globular cells are found caudal to this border and since there is no cytoarchitectonic difference between the areas just rostral and just caudal to the interstitial area, we shall consider both of these areas to be parts of the AVCN.

HRP-stained stellate cells. Forty-six stellate cells were injected intracellularly with HRP. Camera lucida reconstructions of 10 of these cells, chosen for completeness of filling, are shown in Figures 2 and 3. Figure 2 shows stellate cells that are located anterior to the interstitial area; Figure 3 shows some that are located posterior to the interstitial area. The morphology of stellate cells was variable, but this variability was not correlated with position in the nucleus.

The diameter of stellate cell bodies varies between 13 and $21 \mu \mathrm{m}$. Some cell bodies have spines (cells 2, 4, and 5 in Fig. 2; cells 8, 9, and 10 in fig. 3), whereas others do not. Some dendrites are thick and end in highly branched, complex endings (Fig. $1 E$; cells 2 , 4 , and 5 in Fig. 2; cell 10 in Fig. 3), whereas others have thin, filamentous dendrites with terminal thickenings (Fig. $1 F$; cells 1 and 3 in Fig. 2; cells 6, 7, 8, and 9 in Fig. 3). The dendrites of many cells are aligned parallel to the fascicles of auditory nerve fibers (cells 2 and 5 in Fig. 2; cells 6,7 , and 10 in Fig. 3). I lowever, the dendrites of other stellate cells cross auditory nerve fiber fascicles (cells 3 and 4 in Fig. 2; cell 9 in Fig. 3). Dendrites of stellate cells are relatively long, making the diameters of the dendritic fields between 200 and $400 \mu \mathrm{m}$.

Many stellate cells have axon collaterals in the cochlear nuclear complex (cells 2 and 4 in Fig. 2; cell 8 in Fig. 3 ). The collaterals of cell 2 in Figure 2 terminate about $200 \mu \mathrm{m}$ from the cell body in synaptic boutons about 3 $\mu \mathrm{m}$ in diameter (Fig. $1 D$ ). When processes of cells are cut in the preparation of brain slices, the ends apparently reseal and swell. The swollen ends of cut axons can be seen in cells 2, 3, and 4 (Fig. 2) and cells 6, 7 and 8 (Fig. 3 ). The axons of some cells were incompletely stained and could not be followed to their cut ends.

HRP-stained bushy cells. Five of the eight bushy cells injected intracellularly with HRP are shown in Figure 4. Bushy cells were found both anterior (cells 11 and 13) and posterior (cells 14 and 15) to the interstitial area. The cell bodies are covered with spines. They have one or two thick primary dendrites which then branch into many fine, sometimes beaded, ends. The dendrites are short, the dendritic fields being about $100 \mu \mathrm{m}$ in diameter. Where they can be followed, the axons have no collaterals (cell 12, Fig. 4).

Fewer bushy cells were injected with HRP than stellate cells; they seem to be more susceptible to damage with the microelectrode than stellate cells. Initially we used microelectrodes which were beveled (Ogden et al., 1978) to 100 to 150 megohms, filled with $0.5 \mathrm{M}$ potassium chloride and 4\% HRP. With these electrodes only one bushy cell was stained (cell 15). When we changed electrodes to have resistances of between 90 and 100 megohms, filled with $2 \mathrm{M}$ potassium acetate and $2 \% \mathrm{HRP}$ and not beveled, we were able to impale bushy cells regularly. The newer electrodes were presumably finer and sharper.

HRP-stained granule cells. Four of the seven granule cells filled with HRP are shown in Figure 5. The diameter of these cells is about $8 \mu \mathrm{m}$. They have two or three short dendrites which end in curls or claws (Brawer et al., 1974) and which are sparsely covered with very small spines. They have an extremely fine axon which branches close to the cell body. The axons are so fine that they are difficult to see in the light microscope even when the cells are darkly stained. The axons end abruptly without terminal specializations. It is impossible to know whether these ends represent the actual axon terminals or whether the terminals remained unstained.

Type I electrical characteristics. Microelectrodes, especially the large-tipped microelectrodes necessary for the intracellular injection of HRP, often damage the small cells of the mouse cochlear nuclei and make it impossible to determine their physiological properties. However, the impalements of some of the cells depicted in Figures 1 to 4 allowed the properties of cells to be characterized.

Stellate cell 10 (Fig. 3) had type I characteristics (Oertel, 1983). The responses of this cell to electrical stimulation of the auditory nerve at various voltages, 0.1 msec in duration, are shown in Figure 6. Stimulation with a strong shock evoked a suprathreshold excitatory postsynaptic potential (EPSP) (Fig. 6, top trace). The EPSP triggered a large action potential which was followed by an undershoot that obscured all except the beginning of the underlying synaptic potential. Weaker shocks could elicit subthreshold responses of two shapes. Some subthreshold responses rose quickly after a synaptic delay of about $0.8 \mathrm{msec}$ and fell gradually over about 5 msec (Fig. 6, middle (ruce). Others, however, fell more quickly over $2 \mathrm{msec}$ (Fig. 6, bottom trace). It is possible that the EPSP in the lower trace of Figure 6 is truncated by a slightly longer-latency inhibitory postsynaptic potential (IPSP). In this cell an IPSP could not be evoked consistently with subthreshold stimuli; suprathreshold stimuli would have obscured an IPSP.

The intrinsic electrical properties of this cell were determined by the responses to intracellularly injected current pulses, such as those shown on the right in Figure 7. The cell's current-voltage relationship was linear in 


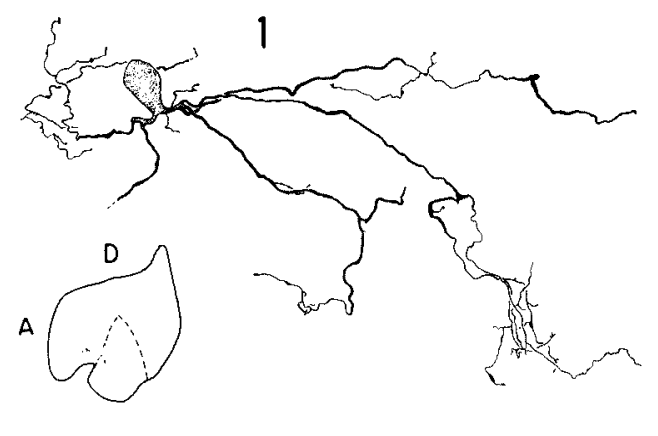

2
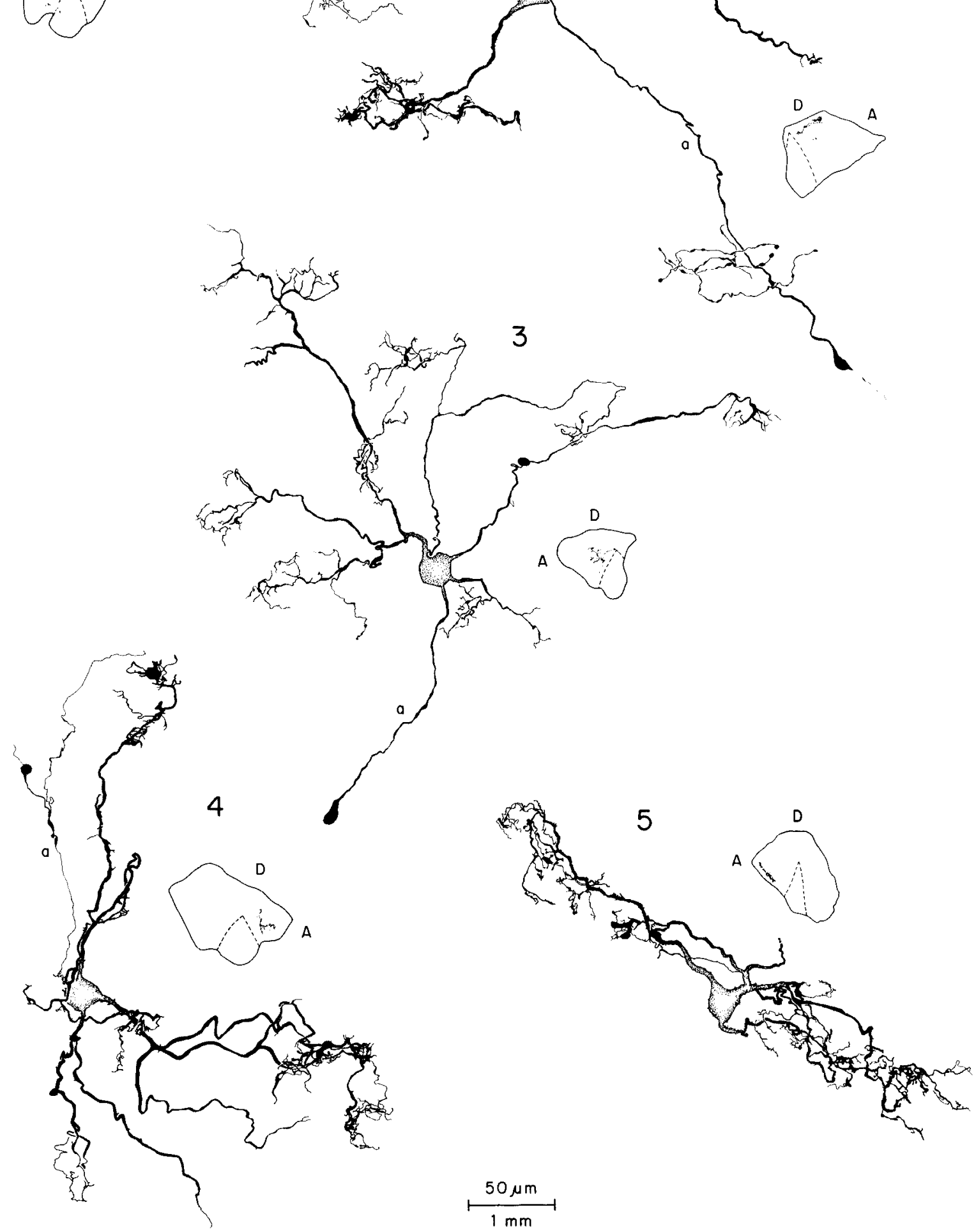

Figure 2. Stellate cells lying anterior to the interstitial area, stained by intracellular injection of HRP. Cell 2 has axon collaterals which terminate a short distance from the cell body. $a$, axon; $A$, anterior; $D$, dorsal. 

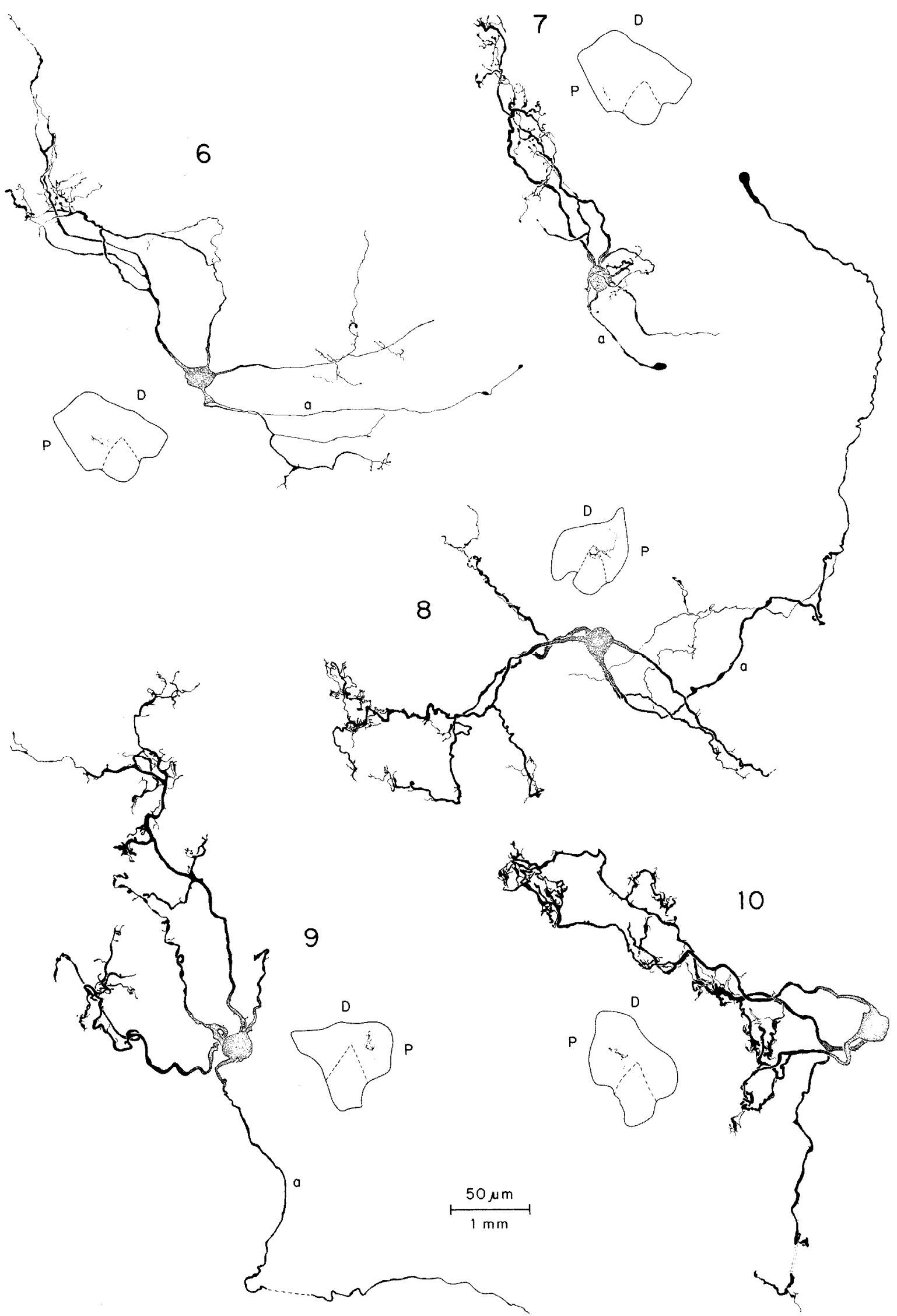

Figure 3. Camera lucida reconstructions of stellate cells lying posterior to the interstitial area, stained by intracellular injection of HRP. $a$, axon; $D$, dorsal; $P$, posterior. 

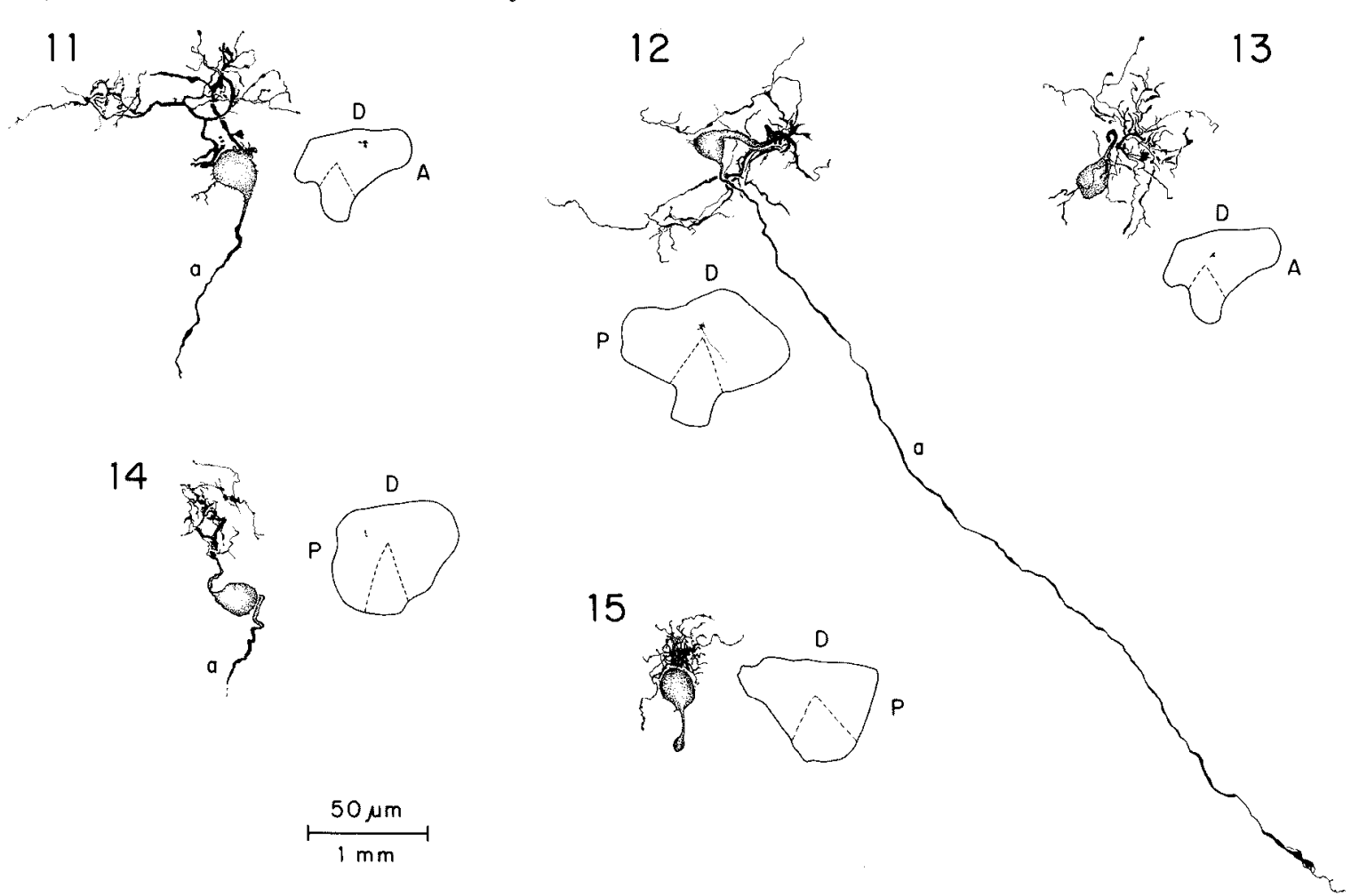

14

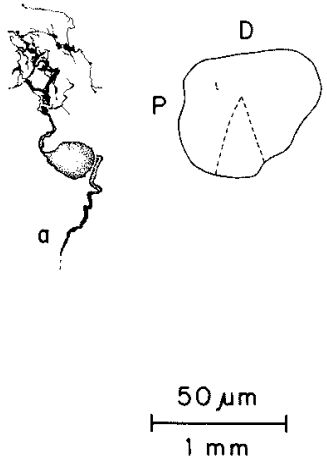

Figure 4. Bushy cells stained by intracellular injection of HRP. $a$, axon; $A$, anterior; $D$, dorsal; $P$, posterior.
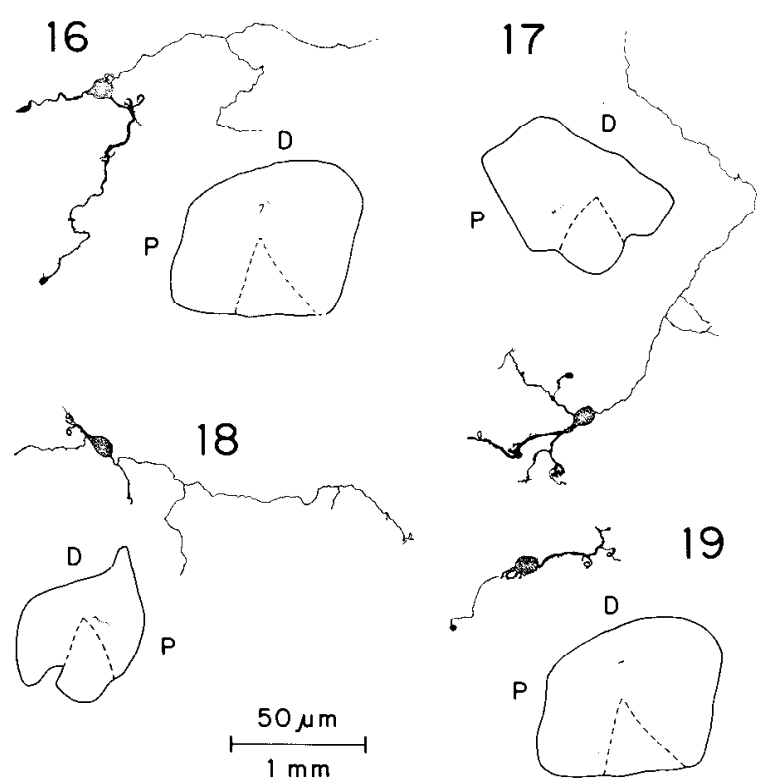

Figure 5. Granule cells stained by intracellular injection of HRP. $D$, dorsal; $P$, posterior.

the subthreshold voltage range, the slope of the function corresponding to an input resistance of 33 megohms (Fig. 7). Suprathreshold depolarizing current pulses elicitcd large, regularly firing action potentials. After the end of a suprathreshold depolarization, the rate at which the cell repolarized was similar to the rate at which the cell repolarized after a hyperpolarization, except when the repolarization occurred during the undershoot of an action potential.

Type II electrical characteristics. Bushy cell 14 (Fig. 4) had type II characteristics. The responses of this cell to electrical stimulation at three strengths are shown in

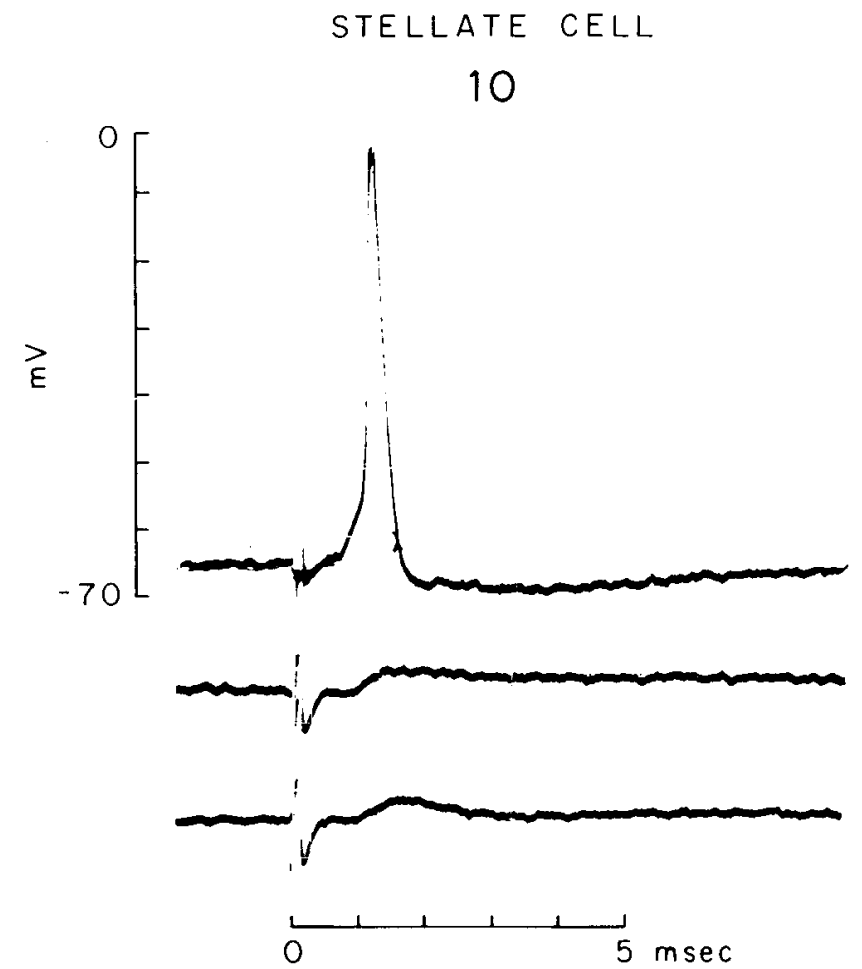

Figure 6. Responses to electrical stimulation of the auditory nerve of stellate cell 10, shown in Figure 3. Upper trace, Suprathreshold synaptic response. Action potential and undershoot are superimposed on the synaptic potentials, obscuring them. Middle trace, Electrical stimulation of auditory nerve at lower strength results in subthreshold EPSP which rises quickly and falls gradually. Lower trace, EPSP is cut short by what is perhaps a longer-latency IPSP. In this cell an IPSP could not be evoked consistently by subthreshold shocks and it would have been obscured by undershoots of action potentials when higher stimulus strengths were used. 


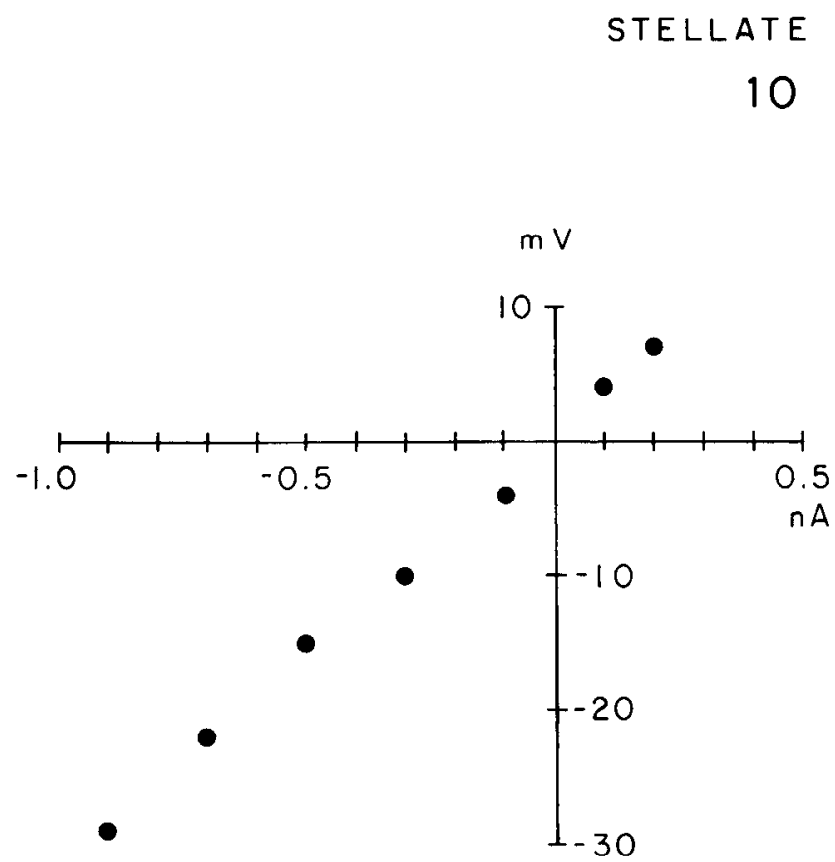

CELL

10

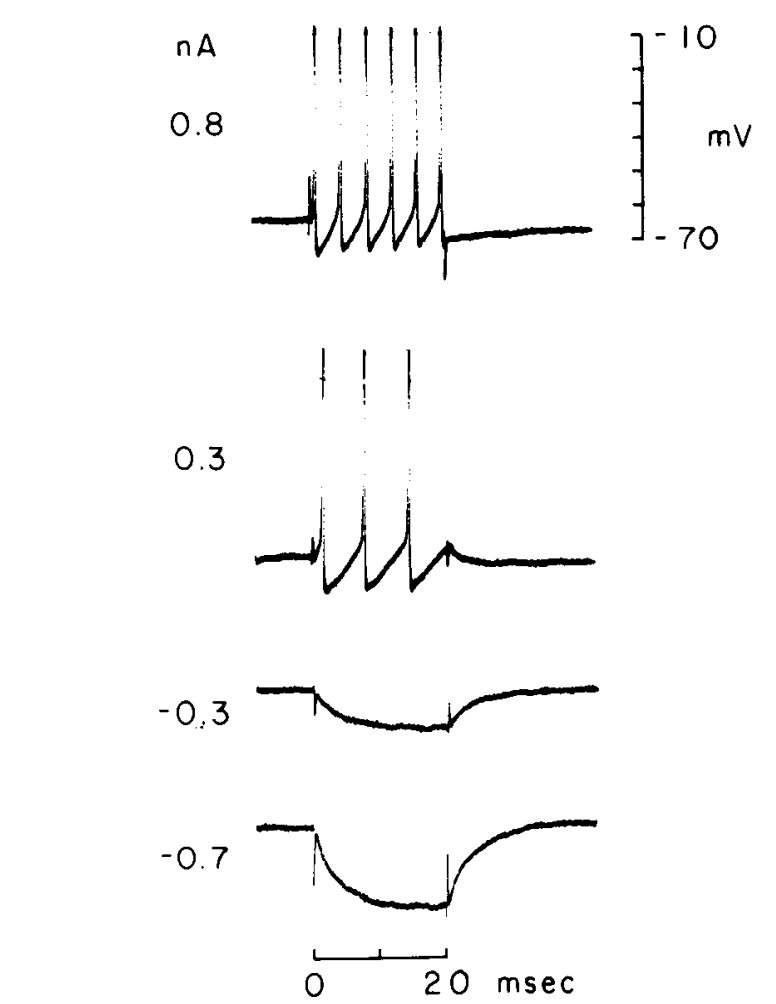

Figure 7. Current-voltage relationship of stellate cell 10, shown in Figure 3 . The plot on the left was made from traces such as those on the right where voltage was measured at the end of the 20 -msec current pulse. Currents $0.3 \mathrm{nA}$ or higher brought the cell to its firing threshold, causing the cell to fire regularly at a rate that depended on the strength of injected current.

Figure $8 A$. The response with the lowest threshold was purely inhibitory and had a latency of $1.6 \mathrm{msec}$. Stronger stimuli elicited large, presumably suprathreshold depolarizations with a latency of $0.5 \mathrm{msec}$. These were followed by hypcrpolarizations of $20 \mathrm{mV}$, about $10 \mathrm{msec}$ long. The experiment illustrated in Figure $8 B$ shows that the IPSP reversed at a level slightly below the cell's resting potential. The bushy cell was polarized with current while it responded to subthreshold stimulation.

Figure $8 B$ illustrates several features of type II characteristics. Depolarizing current elicits only a single, small, brief action potential. After the end of the current pulse the cell repolarizes rapidly, the time constant being about $0.3 \mathrm{msec}$. Hyperpolarizing current of the same magnitude hyperpolarizes the cell further and more slowly, with a time constant of about 5 msec. The peak of the action potential evoked by intracellularly injected current (Fig. $8 B$ ) is smaller than that evoked by stimulation of the auditory nerve (Fig. $8 A$ ).

The results that depolarizing and hyperpolarizing current of equal magnitude and opposite polarity cause voltage changes of different magnitudes suggest that the current-voltage characteristics of this cell are nonlinear. Figure 9 shows the current-voltage plot of bushy cell 14 generated from traces such as those shown on the right. The relationship is indeed nonlinear. The slope of the plot in the hyperpolarizing direction corresponds to an input resistance of about 65 megohms, that in the depo- larizing direction corresponds to an input resistance of about 3 megohms.

Stellate cells have type I characteristics; bushy cells have type II characteristics. Correlation of morphology with physiological characteristics shows that stellate cells have type I and bushy cells have type II electrical properties. Figure 10 summarizes our results. The synaptic responses to electrical stimulation of the auditory nerve before and after the iontophoretic injection of HRP and responses to current pulses of equal magnitude and opposite polarity are shown, together with camera lucida reconstructions of the cells. Responses to current pulses show that stellate cells fire regularly when they are depolarized above threshold; return of the voltage to the resting potential occurs at about similar rates after the end of depolarizing and hyperpolarizing current pulses. These are features of type I characteristics. Bushy cells consistently have asymmetrical responses to injected current of opposite polarity, indicating that they have nonlinear current-voltage characteristics. Synaptic responses are consistently larger than the action potentials evoked with current. In all except one case, the cells remained impaled during the injection with $\mathrm{HRP}$, and in all cases, without exception, only a single cell was injected in the region where electrophysiological recordings were made. In addition to the three stellate cells shown in Figure 10, three cells which had type I characteristics had the long dendrites characteristic of stellate cells. 


\section{BUSHY CELL}

14
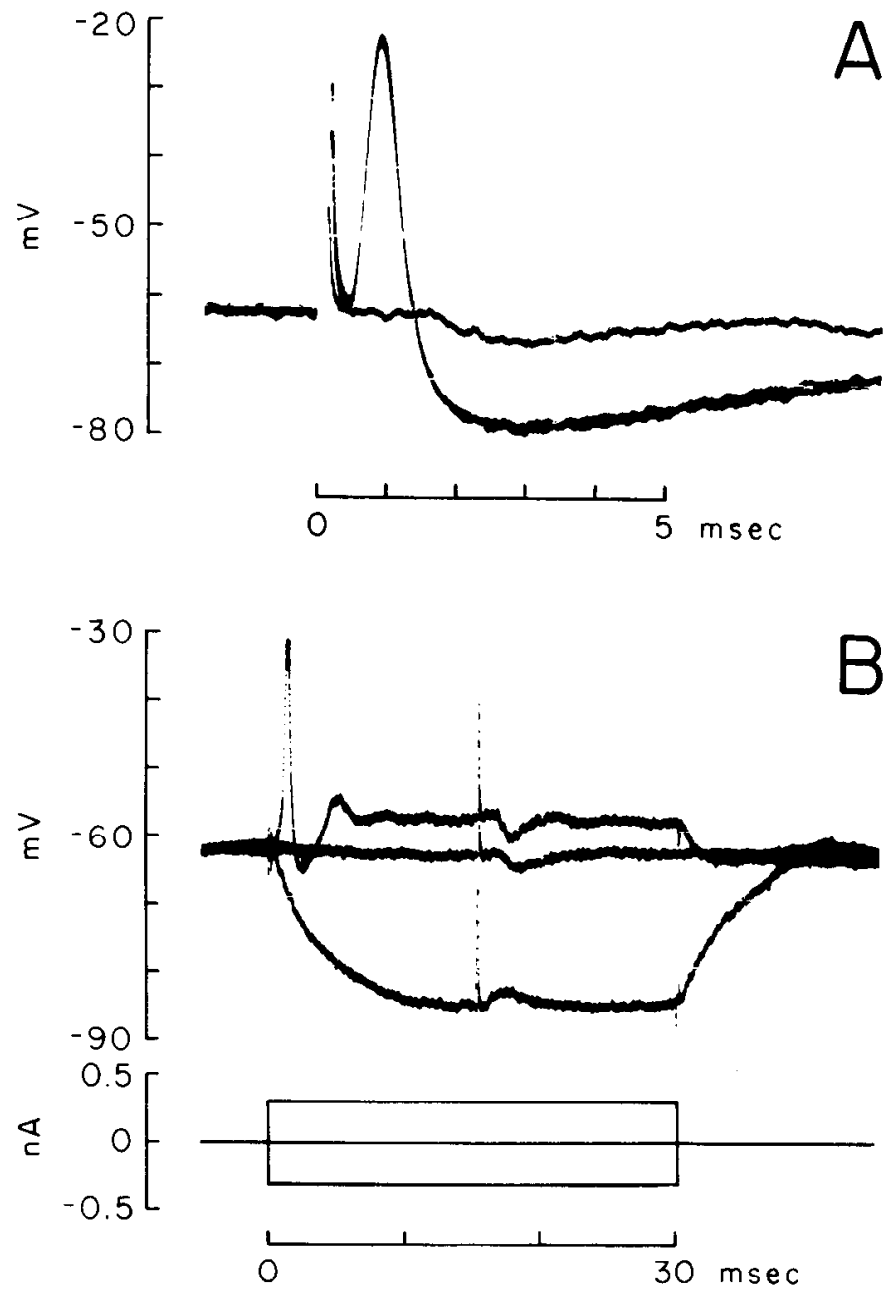

Figure 8. Responses of bushy cell 14 to electrical stimulation of the auditory nerve. $A$, Three superimposed responses to shocks at three different strengths. The response with the lowest threshold was an IPSP. At higher stimulus strengths, suprathreshold excitatory synaptic responses were evoked. The undershoot of the action potential cannot be distinguished from the IPSP. $B$, IPSP reverses at a level lower than the resting potential. Three traces are superimposed in which injected current was varied; synaptic responses were recorded while the cell was polarized with current. Note that suprathreshold depolarization resulted in a single action potential and a small depolarization which returned rapidly to the resting level after the end of the depolarizing current pulse. Hyperpolarization with the same current strength resulted in a larger change in voltage which returned to rest more slowly. Note also that the peak of the synaptically evoked action potential rises higher than that evoked by intracellular current injection.

They are not shown because two of these had swollen dendrites and a third was too lightly stained to be well reconstructed. In addition to the three bushy cells shown in Figure 10, a fourth bushy cell, with type II characteristics, was too lightly stained to be well reconstructed.

The results are summarized in Table I. Eighty-five cells were injected intracellularly with HRP in 24 slice preparations. Sixty-one of these were identified as stel- late cells, bushy cells, or granule cells. Twenty-four other cells were either very pale or swollen. The impalements of 10 of the 61 cells were good enough to identify their electrical characteristics. Six cells with type I characteristics were stellate cells; four cells with type II characteristics were bushy cells.

\section{Discussion}

The results presented above show that the morphology of tissue of brain slice preparations resembles that of tissue which was fixed in situ. In Nissl-stained sections of brain slices of the AVCN of mouse multipolar cells, spherical cells, globular cells, and granule cells can be distinguished (Martin, 1981; Webster and Trune, 1982; Willard and Ryugo, 1983). Cells injected intracellularly with HRP resemble those in Golgi-stained tissue of cat and mouse (Lorente de Nó, 1933b, 1981; Brawer et al., 1974; Cant and Morest, 1979a; Tolbert and Morest, 1982; Webster and Trune, 1982). Stellate cells have relatively large dendritic arborizations extending about $300 \mu \mathrm{m}$ in the parasagittal plane; the thickness of dendrites, the extent of branching, and the endings of dendrites are variable. At least some stellate cells have axons which branch near the cell body and innervate nearby regions in the AVCN with button-shaped terminals. Bushy cells have relatively small dendritic arborizations, extending only about $100 \mu \mathrm{m}$ in the parasagittal plane. They have one or two thick primary dendrites which branch extensively to give them their bushy appearance. Their axons were not seen to branch in the cochlear nuclear complex. Granule cells have three or four short dendrites which do not branch extensively and which often end in a curl or claw (Brawer et al., 1974). Their exceedingly fine axons branch near the cell body and seem to end abruptly without terminal swellings. The morphology of cells anterior and posterior to the interstitial area was similar. We therefore conclude with Willard and Ryugo (1983) that the AVCN of mice extends posterior to the region of bifurcation of auditory nerve fibers in the lateral part of the cochlear nuclear complex.

Stellate cells respond to electrical stimulation of the auditory nerve after a latency of about $0.6 \mathrm{msec}$, with a graded EPSP which lasts approximately $5 \mathrm{msec}$ and which may be followed by a longer-latency IPSP (Oertel, 1983). When stellate cells are depolarized by intracellular injection of current, they fire regularly with large action potentials. Current-voltage plots are linear in the voltage range around the resting potential. Such electrical properties have been termed type I (Oertel, 1983).

Bushy cells respond to electrical stimulation of the auditory nerve with an EPSP after a latency of about 0.6 msec which is often followed by a longer-latency IPSP. When they are depolarized with current, they fire only one or two small action potentials and then remain steadily depolarized. Current-voltage plots are nonlinear around the resting potential. These characteristics have been termed type II (Oertel, 1983).

The membrane properties of bushy cells make them particularly well suited to maintain and convey the precise timing of synaptic inputs. When they are depolarized by intracellularly injected current or by excitatory syn- 

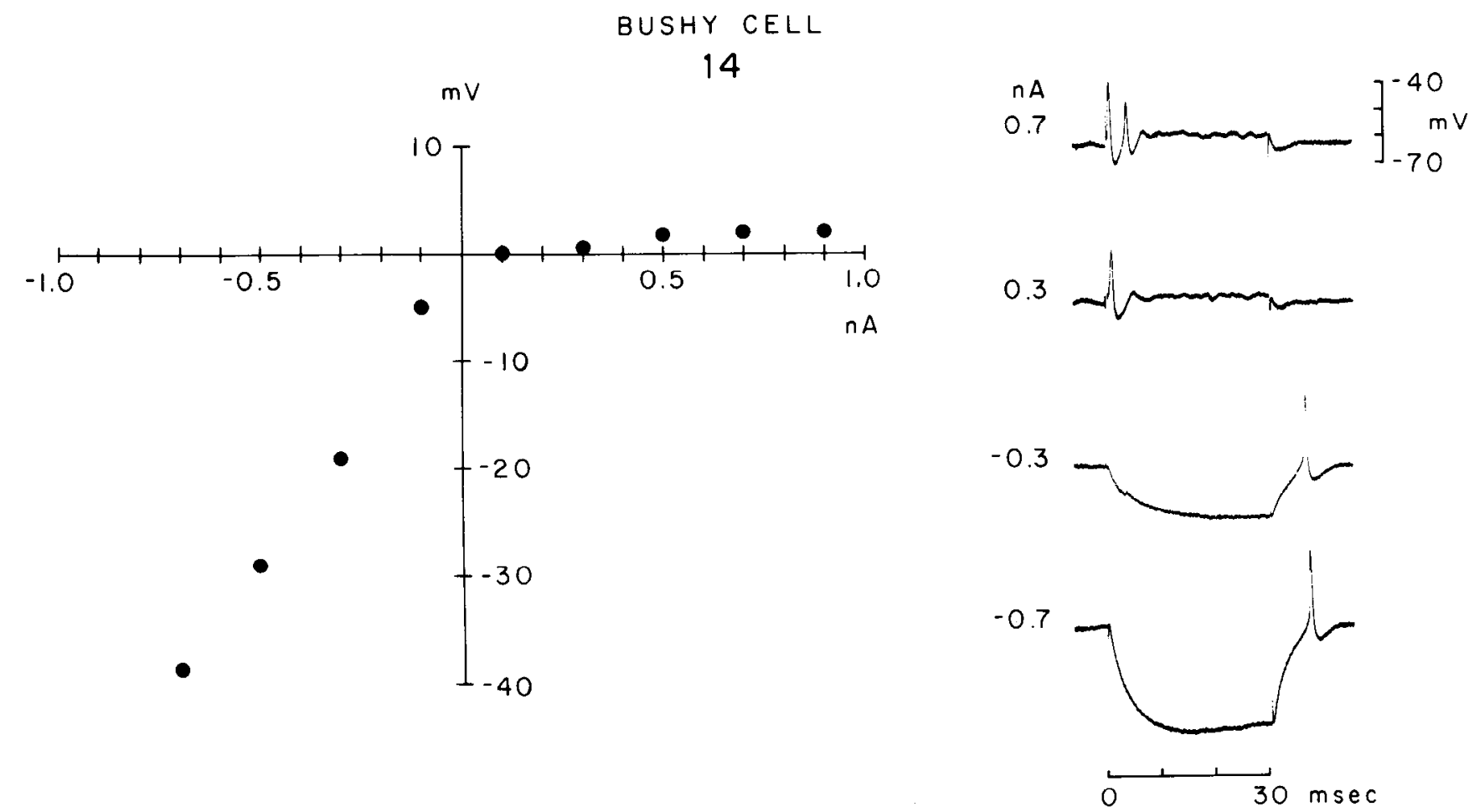

Figure 9. Current-voltage relationship of bushy cell 14. The plot on the left was made from traces such as those on the right, the voltage change being measured at the end of the 30 -msec current pulse. The plot is nonlinear around the resting potential. Suprathreshold depolarizing current elicits only one or two small action potentials and a small voltage change. Hyperpolarizing current produces a large, slow voltage change.

aptic input, the input resistance of bushy cells drops. The rate at which cells repolarize is inversely proportional to the input resistance and therefore increases as the input resistance decreases. Rapid repolarization of EPSPs makes excitatory input brief and prevents summing in time. Therefore, the temporal pattern of excitation of bushy cells can reflect precisely the temporal firing pattern of inputs from auditory nerve fibers.

The low input resistance of bushy cells in the physiological voltage range has two consequences. First, relatively large synaptic currents are needed to provide secure synaptic excitation. The end bulbs of Held are ideally suited to provide large synaptic currents. The observation that the amplitude of synaptic responses is greater than the amplitude of action potentials evoked by intracellular injection of current may reflect the fact that excitatory synaptic currents are relatively large compared with intrinsic voltage-sensitive currents. Evidence that excitatory synaptic currents of cells with type II properties must be large has been discussed in a previous paper (Oertel, 1983). Second, a drop in input resistance will cause passively spread signals to be more strongly attenuated. It is reasonable that cells with properties of bushy cells have only short dendrites and that their major input is on the cell body, near the axon hillock (Lenn and Reese, 1966; Cant and Morest, 1979b).

The finding that stimulation of the auditory nerve caused not only an excitatory synaptic response in bushy and stellate cells in the AVCN but also an inhibitory synaptic response was surprising. It has generally been thought that inhibition plays a small role in the AVCN of the cat (Evans and Nelson, 1973). The present results, together with those of Oertel (1983), show that both stellate and bushy cells receive inhibitory inputs in brain slice preparations. It has been proposed that the inhibitory input arises from cells in the cochlear nuclear complex which are themselves excited by electrical stimulation of the auditory nerve (Oertel, 1983). The source of the inhibitory inputs must be intrinsic to the ventral cochlear nuclei because inhibitory synaptic responses are preserved in slice preparations which lack other parts of the auditory system. Furthermore, the cells providing inhibitory inputs probably lie physically close to the bushy and stellate cells from which intracellular recordings are made because they are present consistently in slice preparations which vary in size and position.

The anatomical results presented above suggest that stellate cells or granule cells could serve as interneurons. Several of the stellate cells injected with HRP have axon collaterals in the cochlear nuclear complex (Fig. 2, cells 2 and 4; and Fig. 3, cell 8). One of these has clear terminations less than $200 \mu \mathrm{m}$ from the cell body (Fig. $1 D$ and Fig. 2, cell 2). Granule cells also have axons that branch close to the cell body which seem to end abruptly, without lerminal specializations, between about 50 and $200 \mu \mathrm{m}$ from the cell body. Bushy cells are unlikely to provide inhibitory inputs to cells in the ventral cochlear nucleus. Axons in bushy cells lack collaterals (Fig. 4; Brawer et al., 1974; Tolbert et al., 1982).

The electrical characteristics of bushy cells in brain slice preparations of the mouse correspond well to the characteristics of bushy cells in the cat from which intracellular recordings have been made. Intracellular recordings from bushy cells showed that they responded to tones with large, graded, brief, and precisely timed depolarizations which showed little temporal summation; 
Synoptic Responses

\section{Before}

STELLATE CELLS

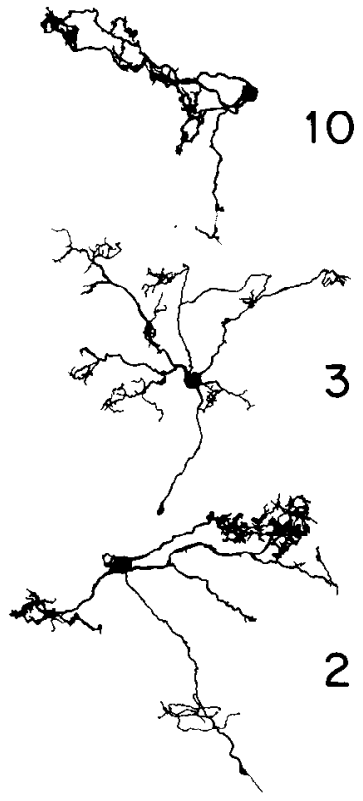

BUSHY CELLS

$m V$
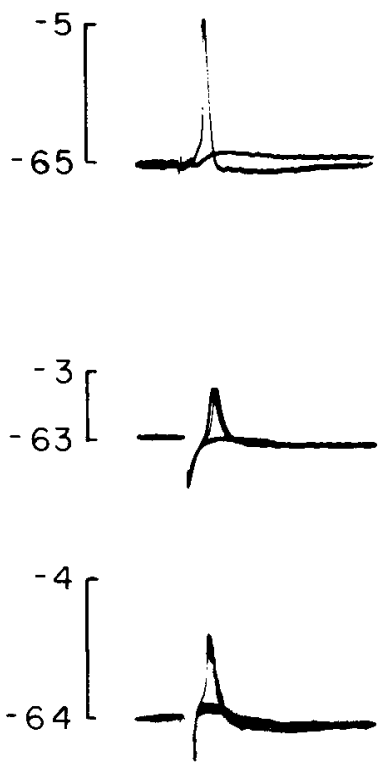
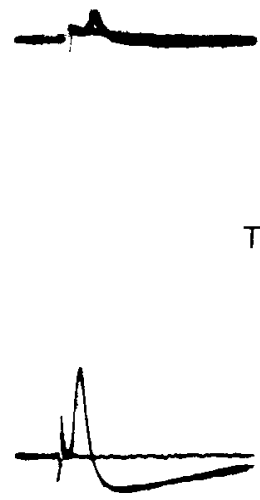

TYPE

Current - Voltoge

Characteristics

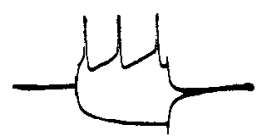

0.3
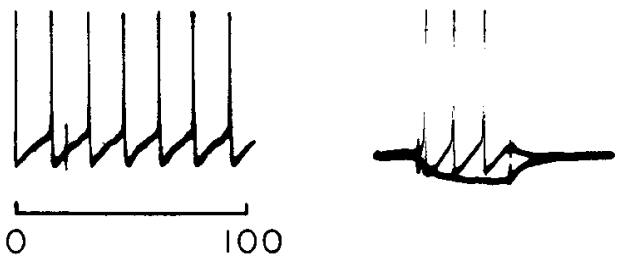

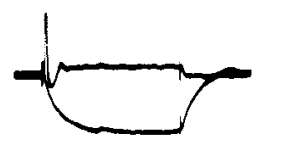

14
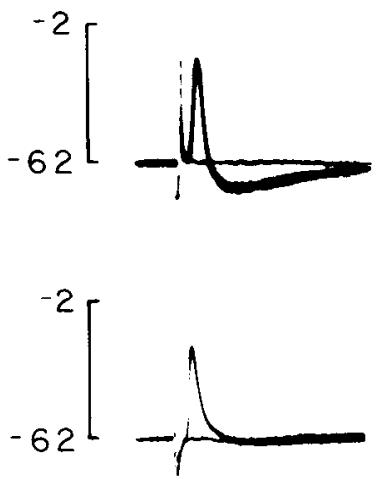

$-60^{0}$

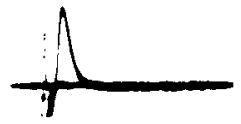$$
\text { O }
$$

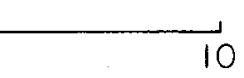

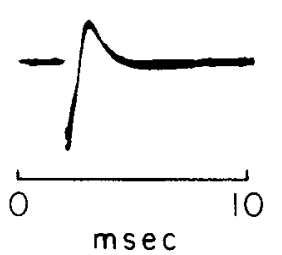
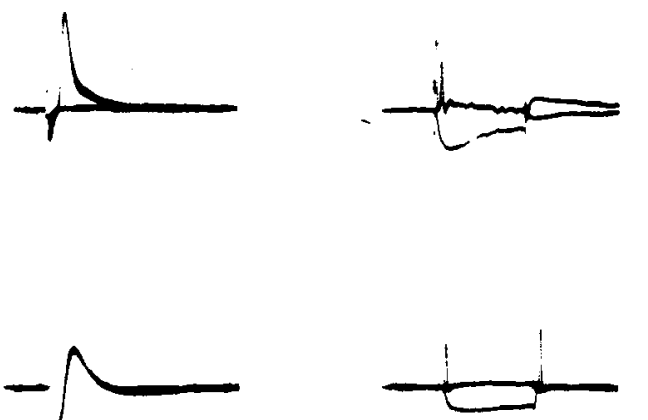

Figure 10. Stellate cells have type I and bushy cells have type II electrical characteristics. The electrophysiological responses in the three right columns were recorded from cells whose morphology is shown on the left. Superimposed synaptic responses to electrical stimulation of the auditory nerve at various strengths are shown before and after iontophoretic injection of HRP. Stellate cell 3 was lost during the injection. Sometimes cells showed signs of damage after injection. Stellate cell 10 fired spontaneously after the injection obscuring the synaptic response. Superimposed responses to intracellular injection of current pulses of equal strength and opposite polarity are shown at the right. Numbers on the right indicate current strength in nanoamperes. 
TABLE I

Summary of results

The number of cells injected intracellularly with HRP is shown in column 2. The impalements of 10 cells allowed electrical properties to be determined. All stellate cells had type I and all bushy cells had type II characteristics. None of the impalements of granule cells were good enough for us to learn anything about their physiology.

\begin{tabular}{lccc}
\hline \multirow{2}{*}{ Cell Type } & No. of Cells & \multicolumn{2}{c}{ Electrical Properties } \\
\cline { 3 - 4 } & & Type I & Type II \\
\hline Stellate cells & 46 & 6 & 0 \\
Bushy cells & 8 & 0 & 4 \\
Granule cells & 7 & & \\
Total & 61 & 6 & 4 \\
\hline
\end{tabular}

action potentials could not be distinguished from synaptic potentials (Rhode et al., 1983). The type II properties of bushy cells are well suited to enable precise temporal coding.

Stellate cells in cats, in contrast to bushy cells, do not maintain temporal coding. They respond to tones with steady, regular firing whose rate depends on intensity but not on the frequency of the tone (Rhode et al., 1983). The type I characteristics of stellate cells are precisely those predicted by Molnar and Pfeiffer (1968) which can result in the "chopper" peristimulus histogram patterns of stellate cells (Oertel, 1983). These cells receive small, temporally summing inputs from the auditory nerve. The morphology of stellate cells makes it likely that spatial summation also occurs.

The results presented above show that stellate and bushy cells have different electrical characteristics. This does not necessarily mean that all stellate cells belong to a single physiological type. In the cat (Lorente de Nó, 1933b, 1981; Brawer et al., 1974) and the mouse (Webster and Trune, 1982) it is obvious that the morphology of stellate cells is diverse. Cant (1981) has shown that, in the anterior division of the AVCN, stellate cells fall into two types depending on whether they receive inputs directly on the cell body. The morphological diversity may well reflect a physiological diversity which is not revealed in these studies.

\section{References}

Adams, J. C. (1977) Technical considerations on the use of horseradish peroxidase as a neuronal marker. Neuroscience 2: $142-145$.

Brawer, J. R., and D. K. Morest (1975) Relations between auditory nerve endings and cell types in the cat's anteroventral cochlear nucleus seen with the Golgi method and Nomarski optics. J. Comp. Neurol. 160: 491-506.

Brawer, J. R., D. K. Morest, and E. C. Kane (1974) The neuronal architecture of the cochlear nucleus of the cat. J. Comp. Neurol. 155: 251-300.

Cant, N. B. (1981) The fine structure of two types of stellate cells in the anterior division of the anteroventral cochlear nucleus of the cat. Neuroscience 6: 2643-2655.

Cant, N. B., and D. K. Morest (1979a) Organization of the neurons in the anterior division of the anteroventral cochlear nucleus of the cat. Light-microscopic observations. Neuroscience 4: 1909-1923.

Cant, N. B., and D. K. Morest (1979b) The bushy cells in the anteroventral cochlear nucleus of the cat. A study with the electron microscope. Neuroscience 4: 1925-1945.

Dingledine, R., J. Dodd, and J. S. Kelly (1980) The in vitro brain slice as a useful neurophysiological preparation for intracellular recording. J. Neurosci. Methods 2: 323-362.

Evans, E. F., and P. G. Nelson (1973) The responses of single neurones in the cochlear nucleus of the cat as a function of their location and anaesthetic state. Exp. Brain Res. 17: 402427.

Graham, R. C., and M. J. Karnovsky (1966) The early stages of absorption of injected horseradish peroxidase in the proximal tubules of mouse kidney: Ultrastructural cytochemistry by a new technique. J. Histochem. Cytochem. 14: 291.

Haberly, L. B., and J. M. Bower (1981) A method for rapid filling of fine-tipped micropipettes with electrolyte solutions including those containing horseradish peroxidase. J. Neurosci. Methods 3: 251-254.

Lenn, N. J., and T. S. Reese (1966) The fine structure of nerve endings in the nucleus of the trapezoid body and the ventral cochlear nucleus. Am. J. Anat. 118: 375-390.

Lorente de Nó, R. (1933a) Anatomy of the eighth nerve. The central projection of the nerve endings of the internal ear. Laryngoscope 43: $1-38$.

Lorente de Nó, R. (1933b) Anatomy of the eighth nerve. III. General plan of the structure of the primary cochlear nuclei. Laryngoscope 43: $327-350$.

Lorente de Nó, R. (1981) The Primary Acoustic Nuclei, Raven Press, New York.

Martin, M. R. (1981) Morphology of the cochlear nucleus of the normal and reeler mutant mouse. J. Comp. Neurol. 197: 141-152.

Molnar, C. E., and R. R. Pfeiffer (1968) Interpretation of spontaneous spike discharge patterns of neurons in the cochlear nucleus. Proc. I.E.E.E. 56: 993-1004.

Oertel, D. (1983) Synaptic responses and electrical properties of cells in brain slices of the mouse anteroventral cochlear nucleus. J. Neurosci. 3: 2043-2053.

Ogden, T. E., M. C. Citron, and R. Pieranto (1978) Jet stream micro-beveler-Inexpensive way to bevel ultrafine glass micropipettes. Science 201: 469-470.

Rhode, W. S., D. Oertel, and P. H. Smith (1983) Physiological response properties of cells labeled intracellularly with horseradish peroxidase in cat ventral cochlear nucleus. J. Comp. Neurol. 213: 448-463.

Rose, J. E., R. Galambos, and J. R. Hughes (1959) Microelectrode studies of the cochlear nuclei of the cat. Bull. Johns Hopkins Hosp. 104: 211-251.

Ryugo, D. K., and D. M. Fekete (1982) Morphology of primary axosomatic endings in the anteroventral cochlear nucleus of the cat: A study of the endbulbs of Held. J. Comp. Neurol. 210: 239-257.

Tolbert, L. P., and D. K. Morest (1982) The neuronal architecture of the anteroventral cochlear nucleus of the cat in the region of the nerve root: Golgi and Nissl methods. Neuroscience 7: 3013-3030.

Tolbert, L. P., D. K. Morest, and D. A. Yurgelun-Todd (1982) The neuronal architecture of the anteroventral cochlear nucleus of the cat in the region of the cochlear nerve root: Horseradish peroxidase labelling of identified cell types. Neuroscience 7: 3031-3052.

Webster, D. B., and D. R. Trune (1982) Cochlear nuclear complex of mice. Am. J. Anat. 163: 103-130.

Willard, F. H., and D. K. Ryugo (1983) Anatomy of the central auditory system. In The Auditory Psychobiology of the Mouse, J. F. Willott, ed., pp. 201-304, Charles C Thomas, Springfield, IL. 